\title{
'Does Your Heart Ache with the Truth of the Past?': Victims and Trauma in Northern Irish Culture
}

\section{Shane Alcobia-Murphy}

The Belfast Agreement, which was signed on 10 April 1998, seemed to place the rights of victims at the heart of its negotiated settlement. Paragraph 11 of the section entitled 'Rights, Safeguards and Equality of Opportunity' declares that ' $[t]$ he participants believe that it is essential to acknowledge and address the suffering of the victims of violence as a necessary element of reconciliation. ${ }^{1}$ These commitments were reiterated in the policy document issued by the Office of the First Minister and Deputy First Minister in 2009: the Strategy for Victims and Survivors states categorically that one of its key aims is to 'put in place comprehensive arrangements to ensure that the voice of victims and survivors is represented and acted upon at a governmental and policy level'. ${ }^{2}$ Indeed, in their advisory document, Dealing with the Past, the Commission for Victims and Survivors noted that 'if we, as a society, keep them [the victims and survivors] at the centre of our approach to dealing with the past we are more likely to address its legacy in ways that are profoundly informed by local insights about human suffering'. ${ }^{3}$ From the vantage point of 2017, one can see that the Agreement did lead to a number of measures being taken to address victims' needs and examine closely the legacy of conflict. Strategic policies and provisions directed at those adversely affected by conflict in Northern Ireland were put in place and have been co-ordinated by key governmental agencies such as the Victims Liaison Unit (1998), the Trauma Advisory Panels (1999) and the Commission for Victims and Survivors (2008). The Office of First Minister and Deputy First Minister (OFMDFM) also issued three key documents focused on reconciliation between the communities: A Shared Future: Policy and Strategic Framework for Good Relations in Northern Ireland (2005), Programme for Cohesion Sharing and Integration (2010) and Together Building a United Community (2013). ${ }^{4}$ In 1998, the Saville Inquiry was announced to look anew at the events of 30 January 1972 in Derry, a day known as Bloody Sunday, and a number of other inquiries were set up 'into disputed killings allegedly resulting from collusion between state security forces and paramilitaries'. ${ }^{5}$ The Agreement also paved the way for the establishment of key bodies whose remit concerned the rights and needs of victims: the Independent Commission for the Location of Victims' Remains (1999), the Northern Ireland Criminal Injuries Compensation Scheme (2002), and the Historical Enquiries Team (2005), a special investigative unit which was granted wide-ranging powers 'to re-

\footnotetext{
${ }^{1}$ Northern Ireland Office, The Belfast Agreement: An Agreement Reached at the Multi-party Talks on Northern Ireland (London: Stationery Office, 20 April 1998), https://www.gov.uk/government/publications/the-belfastagreement. Accessed 20 November 2016.

2 Office of First Minister and Deputy First Minister (OFMDFM), Strategy for Victims and Survivors (Belfast: OFMDFM, 2009), 4.

${ }^{3}$ Commission for Victims and Survivors, Dealing with the Past: Advice to Government (Belfast: CVSNI, 2010), 22.

${ }^{4}$ See OFMDFM, A Shared Future: Policy and Strategic Framework for Good Relations in Northern Ireland, Belfast (Belfast: OFMDFM, 2005); OFMDFM, Programme for Cohesion Sharing and Integration, http://cain.ulst.ac.uk/issues/politics/ofmdfm/ofmdfm_270710_sharing.pdf - accessed 18 November 2016; OFMDFM, Together: Building A United Community (Belfast: OFMDFM, 2013).

${ }^{5}$ See Claire Hackett and Bill Rolston, 'The Burden of Memory: Victims, Storytelling and Resistance in Northern Ireland', Memory Studies 2.3 (2009): 365-6.
} 
examine all deaths attributable to the security situation [...] between 1968-1998' ${ }^{6}$ As Kieran McEvoy and Peter Shirlow have shown, 'over $£ 80$ million has been invested in developing the Northern Ireland victims sector' and 'almost 50 dedicated victim and survivor groups' are in operation in the State. ${ }^{7}$

While money and words were in plentiful supply, the lack of an integrated, cohesive approach was highlighted (and criticised) by the review of the Office of the First Minister and Deputy First Minister's ten-year plan entitled Strategy for Victims and Survivors (2009); the interim report, published in 2013, concluded that 'there is little tangible evidence that the Commission has made a positive difference at the time of the review and limited evidence that it has increased coherence among individuals and groups of/for victims and survivors and made best use of resources' ${ }^{8}$ Indeed, more damningly, although the Consultative Group on the Past called for 'an independent Legacy Commission' to be established 'to deal with the legacy of the past by combining processes of reconciliation, justice and information recovery, ${ }^{9}$ no such Commission has been (or is likely to be) established. Even the much hyped document signed by the Northern Ireland Executive and the UK and Irish governments on 17 November 2015, A Fresh Start: The Stormont Implementation Plan, notes that '[d]espite some significant progress we were not able at this stage to reach a final agreement on the establishment of new bodies to deal with the past'. ${ }^{10}$ A year after its signing, the document's title has come to seem naïve, if not disingenuous: the political impasse on issues to do with the legacies of the past have not been resolved. As Mark Devenport reports, although a series of new agencies have been discussed, 'they remain stillborn, as do proposals from the Lord Chief Justice to accelerate the handling of inquests into contentious killings, many involving the police and army'. ${ }^{11}$

Although 'truth' was deemed 'crucial to the prospect of reconciliation', ${ }^{12}$ the prospects of achieving full disclosure of the State's involvement in paramilitary killings has been hampered by a number of factors. Firstly, the Historical Enquiries Team (HET), charged with investigating 3,268 conflict-related deaths, was found to be less than impartial when examining cases involving State actors: the report issued by Her Majesty's Inspectorate of Constabulary (HMIC) concluded that 'the HET, as a matter of policy, [treated] deaths where there was state involvement differently from those cases where there is no state involvement. State involvement cases appeared to be treated less rigorously'. ${ }^{13}$ The body was

\footnotetext{
${ }^{6}$ Police Service in Northern Ireland, 'Historical Enquiries Team: Policing the Past', http://www/psni.police.uk/historical-enquiries-team/het-background.htm. Accessed 18 November 2016.

${ }^{7}$ Kevin McEvoy and Peter Shirlow, 'The Northern Ireland Peace Process and "Terroristic" Narratives: A Reply to Edwards and McGrattan', Terrorism and Political Violence 25.2 (2013): 164.

${ }^{8}$ KPMG Office of the First Minister and Deputy First Minister, Review of the Commission for Victims and Survivors (2013), 51 - http://www.ofmdfmni.gov.uk/. Accessed 21 November 2016.

${ }^{9}$ Consultative Group on the Past, Report of the Consultative Group on the Past (Belfast: CGP, January 2009), 16.

${ }^{10}$ Theresa Villiers, Secretary of State for Northern Ireland, Foreword to A Fresh Start: The Stormont Agreement and Implementation Plan (Belfast: Northern Ireland Office, 2015), 8.

${ }_{11}$ Mark Devenport, 'The Fresh Agreement One Year on', BBC News Northern Ireland, 17 November 2016, http://www.bbc.co.uk/news/uk-northern-ireland-38016212. Accessed 20 November 2016.

${ }^{12}$ Consultative Group on the Past 25.

${ }^{13}$ Her Majesty's Inspectorate of Constabulary (HMIC), Inspection of the Police Service of Northern Ireland Historical Enquiries Team (2013), https://www.justiceinspectorates.gov.uk/hmic/media/inspection-of-thepolice-service-of-northern-ireland-historical-enquiries-team-20130703.pdf, 100. Accessed 25 November 2016.
} 
subsequently disbanded in 2014 and investigations, including a draft report into collusion by the security forces with the 'Glenanne gang', were effectively shelved. ${ }^{14}$ Secondly, The Inquiries Act (2005) allows the British government to block inquiries into areas that are deemed too sensitive, thereby stalling efforts to facilitate transitional justice: as Lundy and McGovern contend, when establishing the remit and format of an inquiry, the Act 'allows for Ministers to decide whether some evidence can be heard behind closed doors'; hence, the Act delimits 'the potential of such processes to get to the truth' ${ }^{15}$ Thirdly, a perceived lack of political will, on the part of the Westminster and the Democratic Unionist Party, has resulted in funding for enquiries being withheld. For example, the establishment of an enquiry into how eleven civilians were killed between 9-11 August 1971 by members of the $1^{\text {st }}$ Battalion Parachute Regiment has been stymied by both the DUP and the Secretary of State for Northern Ireland, James Brokenshire. When the latter met with the families of the bereaved on 19 September 2016, he was said to have 'refused to answer' key questions and did not allow funding to be released for an inquest. ${ }^{16}$ The families have since been forced to 'to seek judicial review against the Stormont Executive and the British Government'. ${ }^{17}$ Each impediment to uncovering the truth not only confirms Leah Wing's assertion that 'Statesanctioned mechanisms have yet to provide meaningful ways to deal with truth recovery and to tell stories about the past', ${ }^{18}$ but gives rise to the suspicion that what is at work here is what Paul Connerton terms 'prescriptive forgetting', a form of willed amnesia 'precipitated by an act of state' which is 'believed to be in the interests of all the parties to the previous dispute'. ${ }^{19}$ What underlines and drives such forgetting is the fear that the 'awakening' of the dead, rather than 'making whole', would lead to violent retributive action. ${ }^{20}$ Indeed, as we have seen in the introduction to this volume, the opening rhetorical gestures of the Agreement - the swift movement from never forgetting to initiating a 'fresh start' enshrines a progressivist line of thinking: as Stefanie Lehner has argued, '[t]he rhetorical appeal to consign the conflict and its legacy to the distant past discloses a political strategy enforcing a distinct break with the past and the present, in order to open a space for the future'. ${ }^{21}$ If, as Judith Herman contends, 'remembering and telling the truth about terrible events are prerequisites both for the restoration of social order and for the healing of

\footnotetext{
${ }^{14}$ See Alex Thomson, 'Historical Enquiries Team Exposes Northern Ireland Collusion', https://www.channel4.com/news/by/alex-thomson/blogs/historical-enquiries-team-exposes-northernireland-collusion. Accessed 25 November 2016. See also Anne Cadwallader, Lethal Allies: British Collusion in Northern Ireland (Cork: Mercier Press, 2013).

${ }^{15}$ Patricia Lundy and Mark McGovern, 'Truth, Justice and Dealing with the Legacy of the Past in Northern Ireland, 1998-2008', Ethnopolitics 7.1 (2008): 182.

${ }^{16}$ Online Editors, 'Ballymurphy Massacre: Families Walk out of James Brokenshire Stormont Meeting', Belfast Telegraph 19 September 2016, http://www.belfasttelegraph.co.uk/news/northern-ireland/ballymurphymassacre-families-walk-out-of-james-brokenshire-stormont-meeting-35061384.html. Accessed 25 November 2016.

17 Online Editors, 'Ballymurphy Massacre Families Win Battle over Right to Challenge for Inquests Funding', Belfast Telegraph, 14 December 2016, http://www.belfasttelegraph.co.uk/news/northernireland/ballymurphy-massacre-families-win-battle-over-right-to-challenge-for-inquests-funding35293981.html. Accessed 16 December 2016.

${ }^{18}$ Leah Wing, 'Dealing with the Past: Shared and Contested Narratives in "Post-conflict" Northern Ireland', Museum International 62.1-2 (2010): 31.

19 Paul Connerton, The Spirit of Mourning: History, Memory and the Body (Cambridge: CUP, 2011), 34.

${ }^{20}$ Connerton 35.

${ }^{21}$ Stefanie Lehner, 'The Irreversible and the Irrevocable: Encircling Trauma in Contemporary Northern Irish Literature', Memory Ireland: The Famine and the Troubles, ed. Oona Frawley (Syracuse, NY: Syracuse University Press, 2014), 273.
} 
individual victims', ${ }^{22}$ then the opening gesture of the Agreement, with its future-orientated discursive framework and 'progressivist logic', ${ }^{23}$ denies such prerequisites by attempting to write the victims out of history. What this article will go on to explore are the ways in which writers and artists have critiqued both the impetus towards prescriptive forgetting inherent within the Agreement's rhetoric and the mechanisms put in place for dealing with the past; their focus is on those who have been occluded or ignored by the Agreement, namely those who have suffered irreparable loss or who are regarded as 'other' to the State.

As both Emma Grey and Stefanie Lehner suggest elsewhere in this volume, one of the symptoms of post-Agreement amnesia is the proliferation of urban regeneration schemes in Belfast: the urban fabric becomes transformed, erasing markers of conflict and sectarianism. Illustrative of prescriptive forgetting, such a manoeuvre is typical in post-conflict scenarios; as Des O'Rawe and Mark Phelan argue, 'the post-war reconstruction of urban spaces often strives to efface the history and memory of recent conflict'. ${ }^{24}$ However, in her study of the physical remains of conflict in Northern Ireland, Laura McAtackney notes that, while '[t]he creation of material voids, known as "regeneration zones", in place of defunct Army bases, police stations, and check-points' may well arise form and serve to confirm 'the politically negotiated cessation of violent conflict', it does not in and by itself 'indicate any movement towards peace, reconciliation or reconnections within the broader population' ${ }^{25}$ indeed, she concludes that since the 'mass disposal of sites so intrinsically linked to the conflict' have been carried out 'without significant or public engagement', it 'follows a discernible trajectory of post-Troubles political culture that steers towards an official forgetting of the past rather than attempting to uncover and engage with painful truths and accepting responsibilities' ${ }^{26}$ Reacting against such active forgetting, the Derry-born visual artist Willie Doherty created Closure (2007), ${ }^{27}$ a single screen video installation, to reflect upon the idea of place as a repository of memory. For him, it is crucial to sleepwalk towards a form of State-sponsored amnesia: "For me one of the most difficult things about the post-Ceasefire context is the question of how we deal with the aftermath or the trauma. How, as artists, do we begin to visualize it? Is there a kind of a role for artists to play in all this?"28

Watching Closure, the viewer sees a woman dressed in black walking around the perimeter of a narrow, enclosed space. Lasting just over eleven minutes, but played on a loop, the film follows her progress around the space, with the camera always keeping her in the foreground while, at times, cutting to a close-up of her face. The accompanying voiceover provides us with her thoughts: 'My mission is unending. My anger is undiminished. The street is ablaze, The street is twisted. The surface is melting. My ardour is fervent. My passion is

\footnotetext{
22 Judith Herman, Trauma and Recovery (New York: Basic Books, 1997), 1.

${ }^{23}$ See Cillian McGrattan, "'Moving On": The Politics of Shared Society in Northern Ireland', Studies in Ethnicity and Nationalism 12.2 (2012): 172, 175.

24 Des O'Rawe and Mark Phelan, 'Introduction: Cities of Memory', Post-Conflict Performance, Film and visual Arts: Cities of Memory, eds. O'Rawe and Phelan (Basingstoke: Palgrave Macmillan, 2016), 2.

${ }^{25}$ Laura McAtackney, An Archaeology of the Troubles: The Dark Heritage of Long Kesh/Maze Prison (Oxford: OUP, 2014), 3.

${ }^{26}$ McAtackney 3.

${ }^{27}$ See Willie Doherty, Closure, in Willie Doherty: Anthology of Time-Based Works, eds. Yilmaz Dziewior and Matthias Mühling (Ostfildern: Hatje Cantz Verlag, 2007), 142-7.

${ }^{28}$ Willie Doherty in Fionna Barber, 'Ghost Stories: An Interview with Willie Doherty', Visual Culture in Britain 10.2 (2009): 197.
} 
unbowed. The roof is decomposing. The ceiling is dripping. The floor is submerged'. While the woman outwardly appears calm, her thoughts appear dislocated and disjunctive: her trauma is manifest in the fragmented nature of her delivery. Her thoughts move between moments of stoic resolve and reflections on an environment which seems to be collapsing around her, the latter acting as a form of pathetic fallacy. That Doherty gives Closure a circular, looped structure, one that is replayed endlessly in the exhibition space, is crucial as it conveys the subject's experience of trauma: what we witness is trauma in the sense of 'a disease of time [which] permits the past to relive itself in the present, in the form of intrusive images and thoughts' ${ }^{29}$ The idea of achieving closure is belied by the unsettling (and unsettled) nature of her thoughts, the circular journey that she goes on and the looped structure of the artwork. The viewer's sense of an unwanted (and endless) sequence of return is reinforced by the film's location:

That is actually the space in front of an old RUC station in Derry. I managed to negotiate access to the corrugated enclosure she finds herself in, with those crude security measures that grew up around the existing fortifications, although it's not necessary for the viewer to know where it actually is. ${ }^{30}$

While the viewer does not need to know that the film takes place at the site of the former police station at Rosemount, Derry, such knowledge does lend the piece an added poignancy and suggests a direct relevance to the post-Agreement Northern Irish context. The fortified structure, with its 100-foot high surveillance mast, was part of the State's architecture of containment and surveillance during the Troubles; it was a visible manifestation of power and control. As Foucault states, 'le regard qui voit est un regard qui domine'. ${ }^{31}$ The dynamics and regulating power of the State's scopic regime meant that 'life under constant observation became normal', ${ }^{32}$ thereby inducing unease, paranoia and self-scrutiny in the populace. In the Belfast Telegraph, Clare Weir states that the station at Rosemount 'proved contentious for people living in the area' and was certainly out of favour: it was revealed in 2004 that 'just 12 people a year attended the one-man station at a cost of more than $£ 275,000$ to the taxpayer'. ${ }^{33}$ Although the station is now closed, Doherty's artwork suggests that psychological closure has not been achieved.

In a later film, Ancient Ground (2011), Doherty tackles a rather different aspect of willed forgetting. The 8-minute single screen installation is voiced by 'an older woman' which is, he says, 'a fairly direct reference to the plight of the families of those who have disappeared and their engagement with this landscape on an emotional level'. ${ }^{34}$ Here, he is referring to the 'Disappeared' and the traumatic grief suffered by those left without any knowledge of their fate. During the so-called Troubles, seventeen individuals had been abducted, murdered

\footnotetext{
${ }^{29}$ Allan Young, The Harmony of Illusions (Princeton: Princeton University Press, 1997), 7.

30 Doherty in Barber 192.

${ }^{31}$ Michel Foucault, Naissance de la clinique (Paris: Presses Universitaires de France, 1963), 38.

${ }^{32}$ Paula Blair, Old Borders, New Technologies: Reframing Film and Visual Culture in Contemporary Northern Ireland (Oxford: Peter Lang, 2014), 95.

${ }^{33}$ Clare Weir, 'Board Approves Station Closure', Belfast Telegraph 14 December 2006 http://www.belfasttelegraph.co.uk/news/northern-ireland/board-approves-station-closure-28117407.html. Accessed 20 July 2016.

${ }^{34}$ Willie Doherty, interview (2015), https://www.youtube.com/watch?v=yNlxfRNI06w. Accessed 14 December 2016.
} 
and secretly buried by the IRA, and it was only after the Northern Ireland Location of Victims Remains Bill had been passed, effectively granting an amnesty to anyone supplying information as to the whereabouts of the victims, that the IRA issued a statement saying that 'it had identified the location of the bodies' 35 and agreed to supply the information as to their whereabouts. That information was neither as accurate nor as fulsome as had been hoped, and many families were left searching for the remains of their loved ones. In Doherty's work, the camera conducts a slow, forensic search of the landscape (a bog in Co. Donegal), with the voice-over providing a melancholy, almost wistful commentary: 'Hooded. Bound. Weighed down. Discarded. Unmarked. The callousness. The concealment. The fingerprints. The dental records. The femur. The jaw. The ribs. The fibula Preserved. The hair. Compacted. Out of sight. Invisible'. ${ }^{36}$ While the voice meditates on unseen human remains, what the viewer is shown are lingering shots of bog moss and other vegetation, pools of water, holes dug into the surface of the landscape, detritus and other signs of human impress. The landscape on screen is marked by ruptures and open wounds which require our act of witness yet which simultaneously deny access to that which lies hidden; they call to mind to mind the lack of a body over which to mourn and connote not just the haunting fact of loss and the consequent pain of traumatic grief, but also the un-representable nature of loss and trauma. The duration and framing of the shots suggest the stillness of photography, and the tension being played out between presence/absence brings to mind the questions asked by Eduardo Cadava concerning photographs centred on loss:

How can we respond to what is not presently visible, to what can never be seen within the image? To what extent does what is not seen traverse the image as the experience of the interruption of its surface? If the structure of the image is defined as what remains inaccessible to visualization, this withholding and withdrawing structure prevents us from experiencing the image in its entirety, or, to be more precise, encourages us to recognize that the image, bearing as it always does several memories at once, is never closed. ${ }^{37}$

Each of the images in Doherty's film strains (and perhaps ultimately ceases) to function as either a successful textual incorporation or a repository of memory; rather, as Cadava contends, '[e]ffacing what it inscribes, the image bears witness to the impossibility of testimony. It remains as a testament to loss'.$^{38}$ Yet the camera's eye roves on and continues its search: while the circular structure of the film may allude to the temporality of trauma, it equally attests to the filmmaker's unwillingness to cede the duty to remember.

In 2014, Doherty returned this to preoccupation with loss and absence in a 10-minute single screen installation entitled The Amnesiac (2014)..$^{39}$ In the film we see a silent, unnamed individual (played by the well-known Northern Irish actor Stephen Rea) driving along a country road: we observe him through the windscreen, with the reflection of trees scrolling upwards; his face is impassive, eyes staring straight. The film's muted palette and the protagonist's dark clothing accentuate his pallor. Suddenly, he stops the car and we see him

\footnotetext{
${ }^{35}$ Christine Newman, 'Taoiseach Backtracks on Graves Suggestion', Irish Times 18 June 1999.

${ }^{36}$ See Willie Doherty, Ancient Ground in The Disturbance, ed. Barbara Dawson (Dublin: Dublin City Gallery, 2011), 46-75.

${ }^{37}$ Eduardo Cadava, 'Lapsus Imaginis: The Image in Ruins', October 96 (Spring, 2001): 41.

${ }^{38}$ Cadava 49.

${ }^{39}$ See Willie Doherty, The Amnesiac in Willie Doherty: Again and Again (Lisbon: CAM Funaçao Calouste Gulbenkian, 2014), 28-31.
} 
from the inside, his face reflected in (but not looking at) the rearview mirror. And he waits, still staring into space. The press release for the exhibition states that '[h]is journey is interrupted by what might be a momentary lapse in concentration from the tedium of driving, a daydream or a rupture in the fabric of the everyday; a return to somewhere half remembered or half forgotten'. ${ }^{40}$ That 'lapse' impels him to leave the car and wander into the woodland area next to the road, moving ever deeper until he reaches a clearing; once there, he looks down to the ground, almost as if he were searching for something. Next, he stands still and his gaze surveys the vegetation on the woodland's floor and then, in a slow, deliberate fashion, he drops to the ground and stretches out, almost as if he were resting. However, we see him knocking on the ground several times with his fist, listening in vain each time for a response. Since no response is forthcoming, he gets up and stares at the same spot. It is at that point that a rupture occurs: we see another man, shot from above. Reviewing the piece, Declan Long states: 'It is a shocking short of a dead body: a stripped, bound, lifeless form. Face-down in the dirt. What we see may be an hallucination, or a retrieved traumatic memory - a vision, maybe, of a repressed, hidden past that has returned to haunt our preoccupied protagonist'. ${ }^{41}$ The rupture marks the return of the past: it is a form haunting indicative of trauma. As Anthony Roche explains elsewhere in this volume, trauma is, according to Cathy Caruth, 'an overwhelming experience of sudden, or catastrophic events in which the response to the event occurs in the often delayed, and uncontrolled repetitive occurrence of hallucinations and other intrusive phenomena'. ${ }^{42}$ The power of the traumatic experience lies not simply in the fact that it is 'repeated after its forgetting'; rather, as Caruth argues, 'it is only in and through its inherent forgetting that it is first experienced at all., ${ }^{43}$ Since trauma is 'that which resists integration into memory', it is 'an aberration of memory that leaves a body without a context'. ${ }^{44}$ Hence, when the protagonist in Doherty's film experiences the return of the past as a flashback, there is no context for him to understand it: it is, to all intents and purposes, happening again 'for the first time'. Since traumatic experience 'cannot be organised on a linguistic level', the 'failure to arrange the memory in words and symbols leaves it to be organized on a somatosensory or iconic level: as somatic sensations, behavioural re-enactments, nightmares and flashbacks'. ${ }^{45}$ Doherty's film captures the frightening immediacy of this traumatic recall and, since it is without any narrative contextualisation or voice-over, the viewer is put in the protagonist's position, a strategic manoeuvre which facilitates our empathetic engagement with him. However, there is no resolution in The Amnesiac: the protagonist returns to his car and drives on; since the film is on a loop, the viewer is left to watch it happen all over again. Clearly the rupture indicates that time is 'out of joint' - what the protagonist experiences is what Derrida terms a 'disjointed or disadjusted now'46 - but he does not (or is not able to) seek closure. What Doherty points to here is the necessity to engage with the past: willed or involuntary amnesia leads only to repetition and further haunting.

\footnotetext{
${ }^{40}$ Alexander and Bonin Gallery press release, http://www.alexanderandbonin.com/sites/default/files/Image\%20press\%20release_0.pdf. Accessed 20 November 2016.

${ }^{41}$ Declan Long, 'What Lies beneath: The Amnesiac and Other Stories', Willie Doherty: Again and Again (Lisbon: CAM Funaçao Calouste Gulbenkian, 2014), 16.

${ }^{42}$ Cathy Caruth, Unclaimed Experience: Trauma, Narrative, and History (Baltimore, 1996), 11.

${ }^{43}$ Caruth, Unclaimed Experience, 17.

${ }^{44}$ Ulrich Baer, Spectral Evidence: The Photography of Trauma (Cambridge, Mass.: MIT Press, 2002), 18.

${ }^{45}$ Roger Luckhurst, The Trauma Question (London: Routledge, 2008), 148.

${ }^{46}$ Jacques Derrida, Specters of Marx, trans. Peggy Kamuf (1994; London: Routledge, 2006), 4.
} 
However, what may initially seem to be a reasonable and necessary approach is fraught with complications. After all, what happens if the film's protagonist is a perpetrator of violence? (The film does not provide any context or background with which we could assess his status.) Trauma does not only occur to the recipients of violence; a perpetrator is also likely to be haunted by his actions due to an initial failure to 'see' or experience' his past actions. ${ }^{47}$ One poignant example is that of Billy Giles, a member of the UVF, who abducted and shot Michael Fay on 19 November 1982, for which crime he served seventeen years in prison. By choice, he took a life; yet on that night he effectively took a second - his own - though physically it only came to an end when he committed suicide on the night of 24-25 September 1998. In a letter written just prior to his suicide he wrote: 'I was a victim too. Please let our next generation lead normal lives. Tell them of our mistakes and admit to them our regrets. I've decided to bring this to an end now. I'm tired.' ${ }^{\prime 8}$ As Feargal Cochrane notes, opinion is divided in Northern Ireland about exactly who should be treated as a 'victim' and who should be involved in the process of transitional justice: 'For some, restorative justice schemes involving ex-combatants are the way forward - such people were brutalized by political circumstances and would not otherwise have acted as they did [...] For others, this fosters a no-blame history, which absolves those who killed and maimed of guilt' ${ }^{49}$ The attempt to arrive at a fair and clear definition, then, has been a fraught process and has resulted in the creation of what some commentators refer to as 'a hierarchy of victimhood'. ${ }^{50}$ Such a hierarchy, while understandable, is problematic: as Ilanit SimanTov-Nachlieli and Nurit Shnabe note, "[w]hen people think of conflicts, they tend to intuitively perceive the roles of "victims" and "perpetrators" as dichotomous and mutually exclusive'; however, conflicts 'are characterized by "dual" social roles, in the sense that adversaries serve as both victims and perpetrators. ${ }^{.51}$ However, for some commentators, like Cillian McGrattan, there seems to be an unwillingness to countenance engagements with former terrorists as 'victims'. For him, what is needed is 'an ethics of resentment': 52 'an ethical approach to the future demands revulsion at the acts of violence that took place in the past', he argues, and, since these events can never be 'overwritten', 'rather than a bland commitment to inclusion and reconciliation, an ethics of resistance and rejection may create a new platform to discuss the future'.$^{53}$ Yet there is an alternative approach, one perhaps encouraged by Doherty's film. Events cannot be 'overwritten', in the sense that they cannot be (and should not be) denied; however, they can re-contextualised and viewed from different perspectives. To bring an end to 'haunting', one does not have to cast out or deny the presence of ghosts; as Derrida argues, an ethical approach to the past impels us ' $\mathrm{t}$ ] $\mathrm{o}$ exorcise not in order to chase away the ghosts, but this time to grant them the right [...] to [...] a hospitable memory [...] out of a concern for justice'. ${ }^{54}$

\footnotetext{
47 See Gil Z. Hochberg, Visual Occupations: Violence and Visibility in a Conflict Zone (Durham: Duke University Press, 2015), 139-41.

${ }^{48}$ Billy Giles interviewed by Peter Taylor, The Loyalists, BBC documentary (1999), https://www.youtube.com/watch?v=D49qyGBjAag. Accessed 21 November 2016.

${ }^{49}$ Feargal Cochrane, Northern Ireland: The Reluctant Peace (New Haven: Yale University Press, 2013), 295.

${ }^{50}$ See Kirk Simpson, Truth Recovery in Northern Ireland: Critically Interpreting the Past (Manchester: Manchester University Press, 2009), 29.

51 Ilanit SimanTov-Nachlieli and Nurit Shnabe, 'Feeling Both Victim and Perpetrator: Investigating Duality within the Needs-Based Model', Personality and Social Psychology Bulletin 20.10 (2013): 1.

52 McGrattan, “'Moving On”', 186.

53 McGrattan 174.

${ }^{54}$ Derrida 175.
} 
To simply omit certain sections of the population from the conversation about peace - be they victims or perpetrators - is to allow for the return of the past.

The Derridean approach to 'exorcism' is taken in Dave Duggan's AH6905. ${ }^{55}$ The play's premise is that its sole protagonist, Danny, is waiting to appear before a Truth Recovery Commission and is considering whether or not it will do him any good. He is figured as a diseased subject - 'Whole episodes of slaughter, mayhem and callousness are scattered among my vital organs' (AH6905 11) - and testifying before the Commission may well have a potential therapeutic function for him. Although he is aware of his condition and of how the unresolved issues of the past negatively impact upon him - 'The cover-ups, the denials, the disappeared, the lost files, the negligence. Dosed with complications, I am' (AH6905 12) - he appears before the audience as a conflicted individual, at once apprehensive and desirous of a full disclosure of truth. Like Doherty's protagonist in The Amnesiac, Danny is presented as traumatised: 'The dead abound, the dead abound. / How do we keep them in the ground? / The past remains, the past remains' (AH6905 12). This is the refrain which keeps recurring in the play at the moment when a ghost speaks through Danny. It marks the irruption of the past and a form of haunting. ${ }^{56}$ As Avery Gordon notes, in texts marked by trauma 'repressed or unresolved social violence [makes] itself known'; the spectre, or ghostly form, appears and signals that what has been concealed is, in fact, 'very much alive and present' with the capacity to disturb 'those always incomplete forms of containment and repression'. ${ }^{57}$ The repeated statement that 'the past remains' signals the play's concern not just with the physical aftermath of violence but also with the resulting latent trauma. For the traumatized subject, the past is poised around him. Indeed, as Kai Erickson notes, the traumatized mind 'holds on to that moment, preventing it from slipping back into its proper chronological place in the past, and relives it over and over again [...]. The moment becomes a season, the event becomes a condition'. ${ }^{58}$ The progressivist logic of the Agreement is of no use here: the past is now; repressed or ignored, it has returned in full force. The fact that the statement is a refrain, and that the protagonist is repeatedly forced to voice the concerns of the ghosts, can be understood in terms of repetition compulsion. Schwab describes traumatic memories as recurring unconscious thoughts which exist in the memories of the body and its somatic enactments. ${ }^{59}$ As she states, traumatic memories 'entrap us in the prison of repetition compulsion.' 60 'To undo this entrapment, Shoshana Felman and Dori Laub argue that 'a therapeutic process - a process of constructing a narrative, of constructing a history and essentially, of re-externalizing the event - has to be set in motion. ${ }^{61}$ However, '[t]his reexternalization of the event can occur and take effect only when one can articulate and

\footnotetext{
${ }^{55}$ Dave Duggan, AH6905 (Derry: Guildhall Press, 2005). Further references to the text are cited above, marked AH6905.

${ }^{56}$ Caruth, 'Introduction', Trauma: Explorations in Memory, ed. Caruth (Baltimore, Maryland: The Johns Hopkins Press, 1995), 4.

${ }^{57}$ Avery Gordon, Ghostly Matters: Haunting and the Sociological Imagination (Minneapolis: University of Minnesota Press, 2008), xvi.

${ }^{58}$ Kai Erikson, 'Notes on Trauma and Community', Trauma: Explorations in Memory, ed. Cathy Caruth (Baltimore: The John Hopkins University Press, 1995), 185.

${ }^{59}$ Gabriele Schwab, Haunting Legacies: Violent Histories and Transgenerational Trauma (New York: Columbia University Press: 2010), 2.

60 Schwab 2.

${ }^{61}$ Shoshana Felman and Dori Laub, Testimony: Crises of Witnessing in Literature, Psychoanalysis, and History (New York, Routledge: 1992), 69.
} 
transmit the story, literally transfer it to another outside oneself and then take it back again, inside.' 62 Danny's heart may 'ache with the truth of the past' (AH6905 22), but from what the audience witnesses, he is not yet able to fully externalise and articulate a coherent narrative.

Part of the difficulty in interpreting the play lies with the status of its main protagonist. Although in his caustic overview Cillian McGrattan is perhaps justified in his impatience with what he perceives to be Danny's 'trite clichés', 'pseudo-profundities' and 'self-serving doggerel', nevertheless the critic's underlying ire seems to stem from a very basic misreading: he argues from the premise that the protagonist is 'an ex-terrorist' who 'perceives himself as having lost something - the paramilitary motivation shorn of its nationalistic and communalistic verbiage'. ${ }^{63}$ Thus, a play about an ex-terrorist seeking closure is viewed here as a form de-politicisation and moral relativism, ultimately ending in the forgetting of the past. Yet Danny is not simply an 'ex-terrorist': while he may have a physical incarnation as an individual on the stage, he is symbolic of Northern Ireland as a whole. He is shown as having internalised all the Troubles-related deaths ('The dead have infected me. All the dead. Over three and half thousand of them [AH6905 16]) and the actions for which he is responsible suggest no fixed sectarian or political loyalty ('I shot, I bombed, I raided, I shredded, I disappeared, I planned, I colluded, I orchestrated, I planted, I targeted, I informed and I ordered it' [AH6905 19]). Indeed, the first four ghosts which haunt him belong to very different factions: the first ghost is a victim of a car bombing ('Now I ponder, who did this? / Killed me with their bomber's kiss' [AH6905 13]); the second ghost is that of a Republican volunteer ('I was a soldier stern and gave my life / In this ragged post-colonial strife' [AH6905 15]; the third ghost is a dead British soldier 'I should be at home eating hot pots / Instead of guarding this border and ducking pot shots' [AH6905 16]; and the fourth ghost is a Loyalist volunteer who has been killed in an intra-group feud ('used to be comrades, Red Hands linking, / Always loyal, never thinking' [AH6905 20]). A Republican ex-terrorist is unlikely to have been involved in a Loyalist feud or to have killed a member of his own unit (since that death is not presented as stemming from a feud). We are encouraged, then, to think of Danny as a composite figure, as incorporating all factions and all communities. While the play does not resolve the issue of whether a Truth Commission would alleviate suffering - ' $\mathrm{l}$ 'll be hurt by all this truth recover. Maybe it would make me better. Maybe it would make me worse' (AH6905 17) - it does ask the audience to confront a contentious and provocative issue: 'the dead are all equally dead, but in their dying, are they equivalent?' (AH6905 16). Whose story in Northern Ireland is to be remembered? Analysing the effects of the prohibitions on public commemoration, particularly for those viewed as inherently 'other', Judith Butler asks: 'Who counts as human? Whose lives count as lives? [...] What makes for a grievable life?' ${ }^{64}$ It is a question with which our final text grapples in more detail.

In 'The Sands of St. Cyprien', a poem published in a collection of reflections on the 1981 hunger strike edited by Danny Morrison, Medbh McGuckian explores the idea of the victim status of the hunger strikers. Prior to constructing the text, she sought out an historical analogy for the experiences of the Maze prisoners. The text, made up of nine largely unrhymed tercets, is created by splicing together extracts from Spanish Culture behind the Wire, an analysis of oral testimonies and memoirs by Spanish republicans who experienced

\footnotetext{
${ }^{62}$ Felman and Laub 69.

63 McGrattan, Memory, Politics and Identity: Haunted by History (Basingstoke: Palgrave Macmillan, 2013 ), 47.

64 Judith Butler, Precarious Life: The Powers of Mourning and Violence (London: Verso, 2004), 20.
} 
internment by the French in concentration camps located along the open shorelines of Southern France between 1939-1945:65

frozen sand (21); it looked so innocent (72); Footprints were erased and blood was soaked up like water (72)

behind the barbed-wire perimenter (cover); 'The motley group of huts' (164); fistfuls of (30); his very being was slowly being turned into hardened sand (168) 'sand running through my veins' (168) Sand-neurosis (168); sand-induced fits (168) 'the pull of molecules of sand' (177)

the hated sand-jail (184);

'The air was filled with particles of excrement; the discoloured liquid from standing pools of urine blew in our faces' (239); 'little L-shaped pieces' (239)

\author{
Frozen sand: it looked so innocent \\ It erased footsteps and soaked up blood \\ Like water. \\ Behind the barbed-wire perimeter \\ Of that motley group of huts, \\ His very being was fistfuls of hardened sand: \\ Sand running through his veins. \\ Neurosis of sand. Sand induced fits. \\ The pull of molecules of sand. \\ In the sand-jail where consonants burned away, \\ The air was filled with particles \\ Of excrement, little L-shaped pieces ... \\ Discoloured liquid \\ From standing pools of urine \\ Blew their imagined wholeness in their faces.
}

Focusing on the material conditions of imprisonment, the speaker characterizes the inmates' experience as a gradual loss of self, abandoned as they are 'to the alienation of their own abject otherness':66 'wholeness' in such an environment is 'purely imagined'. Here, McGuckian is being faithful to the testimonies collected by Cate-Arries since each tends to recreate 'the place of the camp through tropes of the void, as an unnameable nowhere whose dehumanized and demoralized inhabitants are constantly threatened by the brute forces of both Nature and Man' ${ }^{67}$ Hence, the opening stanzas depict three inter-related types of loss, each symptomatic of a radical dehumanizing alterity: physically ('erased footsteps'; 'soaked up blood'), mentally ('sand-neurosis') and linguistically ('consonants burned away') the individual is stripped of all that defines him as human. Indeed, that 'His very being was fistfuls of hardened sand' is demonstrated by the third stanza's stultifying repetition of 'sand' and the absence of verbs: the text, like the prisoner, is held in stasis.

However, what concerns both Cate-Arries and McGuckian is not simply loss as immediately experienced as a result of incarceration; rather, both their texts highlight the more insidious process of othering whereby the events themselves become altered by or erased from historical record, and both authors explicitly seek to recover occluded narratives:

I don't know if I read it in a newspaper or if someone told me (48)

twenty-four hours have gone by (156)
I don't know if I read it in a newspaper, Or if someone told me,

Or if I heard it after twenty-four hours had gone by:

\footnotetext{
65 Medbh McGuckian, 'The Sands of St. Cyprien', Hunger Strike, ed. Danny Morrison (Dublin: Brandon Books, 2007), 196. McGuckian's text is on the right; on the left are quotations from Francie Cate-Arries, Spanish Culture behind the Wire: Memory and Representation of the French Concentration Camps, 1939-1945 (Lewisburg: Bucknell University Press, 2004).

${ }^{66}$ Cate-Arries 238.

${ }^{67}$ Cate-Arries 22.
} 
Nothing reported could be further from the truth (239)
But nothing reported could have been

Further from the truth [...]

'Truth', of course, is a problematic term, particularly in a poem which explicitly parallels the prison experiences of republicans from wholly disparate locations and time periods, as exemplified by the poem's title - 'The Sands of St. Cyprien' - which works geologically (the beach environment) as well as patronymically (Bobby Sands). Indeed, the images used from the accounts of the French camps to evoke both the Dirty Protest and the 1981 hunger strike - 'skeleton in a blanket'; 'a carcass in manure' - are inaccurate since they conflate the three different phases of the republican struggle within the Maze. Nevertheless, a poem is not a historical narrative: its purpose here serves as a call to remember the suffering endured by the prisoners and to counter the dehumanising strategies of those who choose not to recognise their humanity. (That, of course, is not the same as either forgetting or forgiving the actions which led to them being imprisoned.) In an accompanying essay, the poet speculates on the lack of commemorative verse for the ten dead hunger-strikers: "Why, we may ask, is there no poem of the stature and resonance of "Easter 1916" for these ten men? [...] Because these men were merely "the scum of the earth" and deserved no epitaph?' ${ }^{68}$

The Agreement may urge us to initiate a 'fresh start', yet that cannot be achieved if the crimes and traumas of the past are to be ignored, or if the stories of certain sections of the population are to go unheard. Many Northern Irish writers and artists resist the Agreement's progressivist logic and highlight the dangers of neglecting the past. While the issue of whether or not a perpetrator can be regarded as a victim is a thorny one, the works discussed here do not shy away from alerting us to their stories. Rather than foreground the imperatives to forgive and forget, or highlight the need to enter into the seductive embrace of cultural amnesia, or promote what Senator George Mitchell termed 'the decommissioning of mindsets', 69 much Northern Irish art focuses upon the dangers of forgetting the past. For the visual artists and writers alike, a wilful neglect of history may result in the return of the repressed and in psychic breakdown on both the communal and individual levels. Thus, contrary to those who indulged in the euphoric post-conflict jubilation, writers and artists like the poet Michael Longley weighed in with prudent counsel, arguing that 'amnesty isn't amnesia' and that '[i]n order to make sure it doesn't happen again, you've got to remember it in great detail. Those who forget history are the ones who are doomed to repeat it'. ${ }^{70}$

\section{Works Cited}

Alexander and Bonin Gallery. Press Release.

http://www.alexanderandbonin.com/sites/default/files/Image\%20press\%20release_ $0 . p d f$.

Baer, Ulrich. Spectral Evidence: The Photography of Trauma. Cambridge, Mass.: MIT Press, 2002.

Barber, Fionna. 'Ghost Stories: An Interview with Willie Doherty'. Visual Culture in Britain.

\footnotetext{
68 McGuckian, 'The Desire for Freedom', Hunger Strike, ed. Danny Morrison, 192.

${ }^{69}$ Senator George Mitchell cited in BBC Northern Ireland, 'Does Decommissioning Mean Peace?', http://news.bbc.co.uk/1/hi/northern_ireland/4291148.stm. Accessed 18 June 2016.

70 Michael Longley, "“Walking Forwards into the Past": An Interview with Michael Longley', interview by Fran Brearton, Irish Studies Review 18 (Spring, 1997): 35-6.
} 
10.2 (2009): 189-99.

Blair, Paula. Old Borders, New Technologies: Reframing Film and Visual Culture in Contemporary Northern Ireland. Oxford: Peter Lang, 2014.

Butler, Judith. Precarious Life: The Powers of Mourning and Violence. London: Verso, 2004. Cadava, Eduardo. 'Lapsus Imaginis: The Image in Ruins'. October 96. (Spring, 2001): 35-60.

Cadwallader, Anne. Lethal Allies: British Collusion in Northern Ireland. Cork: Mercier Press, 2013.

Caruth, Cathy. 'Introduction'. Trauma: Explorations in Memory. Ed. Caruth. Baltimore, Maryland: The Johns Hopkins Press, 1995. 3-12.

Caruth, Cathy. Unclaimed Experience: Trauma, Narrative, and History. Baltimore, 1996.

Cate-Arries, Francie. Spanish Culture behind the Wire: Memory and Representation of the French Concentration Camps, 1939-1945. Lewisburg: Bucknell University Press, 2004.

Cochrane, Feargal. Northern Ireland: The Reluctant Peace. New Haven: Yale University Press, 2013.

Commission for Victims and Survivors. Dealing with the Past: Advice to Government. Belfast: CVSNI, 2010.

Connerton, Paul. The Spirit of Mourning: History, Memory and the Body. Cambridge: CUP, 2011.

Consultative Group on the Past. Report of the Consultative Group on the Past. Belfast: CGP, 2009.

Derrida, Jacques. Specters of Marx. Trans. Peggy Kamuf. 1994; London: Routledge, 2006.

Devenport, Mark. 'The Fresh Agreement One Year on'. BBC News Northern Ireland. 17 November 2016. http://www.bbc.co.uk/news/uk-northern-ireland-38016212.

Doherty, Willie. Closure. Willie Doherty: Anthology of Time-Based Works. Eds. Yilmaz Dziewior and Matthias Mühling. Ostfildern: Hatje Cantz Verlag, 2007. 142-7.

Doherty, Willie. Ancient Ground. The Disturbance. Ed. Barbara Dawson. Dublin: Dublin City Gallery, 2011. 46-75.

Doherty, Willie. The Amnesiac. Willie Doherty: Again and Again. Lisbon: CAM Funaçao Calouste Gulbenkian, 2014. 28-31.

Doherty, Willie. Interview. 2015. https://www.youtube.com/watch?v=yNIxfRNI06w.

Duggan, Dave. AH6905. Derry: Guildhall Press, 2005.

Erikson, Kai. 'Notes on Trauma and Community'. Trauma: Explorations in Memory. Ed. Cathy Caruth. Baltimore: The John Hopkins University Press, 1995. 182-99.

Felman, Shoshana and Dori Laub. Testimony: Crises of Witnessing in Literature, Psychoanalysis, and History. New York, Routledge: 1992.

Foucault, Michel. Naissance de la Clinique. Paris: Presses Universitaires de France, 1963.

Gordon, Avery. Ghostly Matters: Haunting and the Sociological Imagination. Minneapolis: University of Minnesota Press, 2008.

Hackett, Claire and Bill Rolston. 'The Burden of Memory: Victims, Storytelling and Resistance in Northern Ireland'. Memory Studies. 2.3 (2009): 355-76.

Her Majesty's Inspectorate of Constabulary (HMIC). Inspection of the Police Service of Northern Ireland Historical Enquiries Team (2013).

https://www.justiceinspectorates.gov.uk/hmic/media/inspection-of-the-policeservice-of-northern-ireland-historical-enquiries-team-20130703.pdf.

Herman, Judith. Trauma and Recovery. New York: Basic Books, 1997.

Hochberg, Gil Z. Visual Occupations: Violence and Visibility in a Conflict Zone. Durham: Duke University Press, 2015. 
Lehner, Stefanie. 'The Irreversible and the Irrevocable: Encircling Trauma in Contemporary Northern Irish Literature'. Memory Ireland: The Famine and the Troubles. Ed. Oona Frawley. Syracuse, NY: Syracuse University Press, 2014.

Long, Declan. 'What Lies beneath: The Amnesiac and Other Stories'. Willie Doherty: Again and Again. Lisbon: CAM Funaçao Calouste Gulbenkian, 2014. 15-22.

Longley, Michael. "Walking Forwards into the Past": An Interview with Michael Longley'. Interview by Fran Brearton. Irish Studies Review. 18 (Spring, 1997): 35-9.

Luckhurst, Roger. The Trauma Question. London: Routledge, 2008.

Lundy, Patricia and Mark McGovern. 'Truth, Justice and Dealing with the Legacy of the Past in Northern Ireland, 1998-2008'. Ethnopolitics. 7.1 (2008): 177-93.

McAtackney, Laura. An Archaeology of the Troubles: The Dark Heritage of Long Kesh/Maze Prison. Oxford: OUP, 2014.

McEvoy, Kevin and Peter Shirlow. 'The Northern Ireland Peace Process and "Terroristic" Narratives: A Reply to Edwards and McGrattan'. Terrorism and Political Violence. 25.2 (2013): 161-66.

McGrattan, Cillian. "'Moving On": The Politics of Shared Society in Northern Ireland'. Studies in Ethnicity and Nationalism. 12.2 (2012): 172-89.

McGrattan, Cillian. Memory, Politics and Identity: Haunted by History. Basingstoke: Palgrave Macmillan, 2013.

McGuckian, Medbh. 'The Sands of St. Cyprien'. Hunger Strike. Ed. Danny Morrison. Dublin: Brandon Books, 2007. 196.

McGuckian, Medbh. 'The Desire for Freedom'. Hunger Strike. Ed. Danny Morrison. Dublin: Brandon Books, 2007. 192-5.

Newman, Christine. 'Taoiseach Backtracks on Graves Suggestion'. Irish Times. 18 June 1999.

Northern Ireland Office. The Belfast Agreement: An Agreement Reached at the Multi-party Talks on Northern Ireland. London: Stationery Office, 20 April 1998. https://www.gov.uk/government/publications/the-belfast-agreement.

Office of First Minister and Deputy First Minister (OFMDFM). A Shared Future: Policy and Strategic Framework for Good Relations in Northern Ireland, Belfast. Belfast: OFMDFM, 2005.

Office of First Minister and Deputy First Minister (OFMDFM). Strategy for Victims and Survivors. Belfast: OFMDFM, 2009.

Office of First Minister and Deputy First Minister (OFMDFM). Programme for Cohesion Sharing and Integration. http://cain.ulst.ac.uk/issues/politics/ofmdfm/ofmdfm_270710_sharing.pdf.

Office of First Minister and Deputy First Minister (OFMDFM). Together: Building A United Community. Belfast: OFMDFM, 2013.

Office of the First Minister and Deputy First Minister, Review of the Commission for Victims and Survivors (2013). http://www.ofmdfmni.gov.uk/.

Online Editors. 'Ballymurphy Massacre: Families Walk out of James Brokenshire Stormont Meeting'. Belfast Telegraph. 19 September 2016. http://www.belfasttelegraph.co.uk/news/northern-ireland/ballymurphy-massacrefamilies-walk-out-of-james-brokenshire-stormont-meeting-35061384.html.

Online Editors. 'Ballymurphy Massacre Families Win Battle over Right to Challenge for Inquests Funding'. Belfast Telegraph. 14 December 2016. http://www.belfasttelegraph.co.uk/news/northern-ireland/ballymurphy-massacrefamilies-win-battle-over-right-to-challenge-for-inquests-funding-35293981.html. 
O’Rawe, Des and Mark Phelan. 'Introduction: Cities of Memory'. Post-Conflict Performance, Film and visual Arts: Cities of Memory. Eds. O'Rawe and Phelan. Basingstoke: Palgrave Macmillan, 2016. 1-11.

Police Service in Northern Ireland. 'Historical Enquiries Team: Policing the Past'. http://www/psni.police.uk/historical-enquiries-team/het-background.htm.

Schwab, Gabriele. Haunting Legacies: Violent Histories and Transgenerational Trauma. New York: Columbia University Press: 2010.

SimanTov-Nachlieli, Ilanit and Nurit Shnabe. 'Feeling Both Victim and Perpetrator: Investigating Duality within the Needs-Based Model'. Personality and Social Psychology Bulletin. 20.10 (2013): 1-14.

Simpson, Kirk. Truth Recovery in Northern Ireland: Critically Interpreting the Past. Manchester: Manchester University Press, 2009.

Taylor, Peter. The Loyalists. BBC Documentary. 1999. https://www.youtube.com/watch?v=D49qyGBjAag. Accessed 21 November 2016.

Thomson, Alex. 'Historical Enquiries Team Exposes Northern Ireland Collusion'. https://www.channel4.com/news/by/alex-thomson/blogs/historical-enquiries-teamexposes-northern-ireland-collusion.

Villiers, Theresa. 'Foreword'. A Fresh Start: The Stormont Agreement and Implementation Plan. Belfast: Northern Ireland Office, 2015. 7-8.

Weir, Clare. 'Board Approves Station Closure'. Belfast Telegraph. 14 December 2006. http://www.belfasttelegraph.co.uk/news/northern-ireland/board-approves-stationclosure-28117407.html.

Wing, Leah. 'Dealing with the Past: Shared and Contested Narratives in "Post-conflict" Northern Ireland'. Museum International. 62.1-2 (2010): 31-6.

Young, Allan. The Harmony of Illusions. Princeton: Princeton University Press, 1997. 